\title{
Trickle irrigation systems affect spatial distribution of roots of banana crop
}

\author{
Edvaldo B. Santana Junior' ${ }^{1}$, Eugênio F. Coelho², Jailson L. Cruz², João B. R. da S. Reis ${ }^{3}$, \\ Diego M. de Mello $\&$ Bruno L. da S. Pereira ${ }^{4}$ \\ ${ }^{1}$ Instituto Federal do Piauí/Campus Paulistana, Paulistana, PI, Brasil. E-mail: edvaldobispo@gmail.com - ORCID: 0000-0001-6133-4096 \\ ${ }^{2}$ Embrapa Mandioca e Fruticultura, Cruz das Almas, BA, Brasil. E-mail: eugenio.coelho@embrapa.br - ORCID: 0000-0001-7079-6858; jailson.cruz@embrapa.br - \\ ORCID: 0000-0002-2536-6143 \\ ${ }^{3}$ Empresa de Pesquisa Agropecuária de Minas Gerais, Nova Porteirinha, MG, Brasil. E-mail: jbrsreis@epamig.br (Corresponding author) - ORCID:0000-0001-5677-605X \\ ${ }^{4}$ Universidade Federal do Recôncavo da Bahia/Programa de Pós-Graduação em Engenharia Agrícola, Cruz das Almas, BA, Brasil. E-mail: engdmmelo@gmail.com - \\ ORCID: 0000-0003-0198-1130; brunolaecio_3@hotmail.com - ORCID: 0000-0001-5784-5512
}

\begin{abstract}
Trickle irrigation has been largely used for banana in Brazil, mainly due to the increase in water and fertilizer use efficiency. These irrigation systems have different options concerning number, type and flow rate of emitters as well as for hydraulics, number and location of lateral lines. The small area of soil wetted by these systems limits root spatial distribution of crops. This study aimed to evaluate the effect of different trickle irrigation systems on the root spatial growth and root spatial distribution of banana cv. Prata Gorutuba. Root length density and root length were evaluated in soil profiles of three micro-sprinkler systems, with emitter flow rates of 35, 53 and $70 \mathrm{~L} \mathrm{~h}^{-1}$ and of two drip irrigation systems, with one and two lateral lines per crop row. Trickle irrigation systems influence root spatial distribution, favoring a greater or smaller distribution of roots at different depth and distance from the plant according to micro-sprinkler flow rate and to the number of lateral lines per crop row. The effect on root spatial distribution is more accentuated for micro-sprinkler systems than for drip systems. The majority of the total root length (80\%) was observed in the soil profiles from 0.33 to $0.57 \mathrm{~m}$ depth and at distances from the plants of 0.75 to $0.83 \mathrm{~m}$.
\end{abstract}

Key words: Musa sp., micro-sprinkler, drip system, root length density

\section{Sistemas de irrigação localizada influenciam a distribuição espacial das raízes da cultura da bananeira}

RESUMO: A irrigação localizada tem sido amplamente utilizada para a cultura da banana nos projetos de irrigação do Brasil, principalmente devido ao aumento da eficiência do uso de água e fertilizantes para as culturas. Estes sistemas de irrigação apresentam diferentes opções relativas ao número, tipo e taxa de vazão dos emissores, bem como para a hidráulica, número e localização das linhas laterais. A pequena área do solo molhada por esses sistemas limita a distribuição espacial das raízes das culturas. Este estudo teve como objetivo avaliar o efeito de diferentes sistemas de irrigação localizada no crescimento e na distribuição espacial de raízes de bananeira cv. Prata Gorutuba. A densidade do comprimento radicular e o comprimento das raízes foram avaliados em perfis de três sistemas de microaspersão, com vazões de $35,53 \mathrm{e} 70 \mathrm{~L} \mathrm{~h}^{-1}$ e de dois sistemas de irrigação por gotejamento, com uma e duas linhas laterais por linha de cultivo. Os sistemas de irrigação localizada influenciam a distribuição espacial das raízes favorecendo uma maior ou menor distribuição das raízes em diferentes profundidades e distâncias da planta de acordo com a vazão do microaspersor e o número de linhas laterais na linha da cultura. O efeito na distribuição espacial das raízes é mais acentuado para os sistemas de microaspersão do que para os sistemas de gotejamento. Grande parte do comprimento total das raízes $(80 \%)$ nos perfís do solo estava na camada de 0,33 a $0,57 \mathrm{~m}$ de profundidade e a distâncias das plantas de 0,75 a $0,83 \mathrm{~m}$.

Palavras-chave: Musa sp., microaspersão, sistema de gotejamento, densidade do comprimento das raízes 


\section{INTRODUCTION}

The cultivation of irrigated banana commonly uses trickle irrigation combined with fertigation, since these practices enhance the efficiency of application of water and fertilizers, because trickle irrigation methods apply water close to the root system (Pramanik et al., 2016; Pawar et al., 2017). Drip irrigation systems, in the field, may have a different number of lateral lines per plant row, number of emitters per plant, and distribution of emitters around plants. These variables are responsible for water distribution in the soil, which can impact the crop depending on the adopted configuration, since different configurations of drip irrigation systems will influence the root systems of plants. Knowledge about spatial distribution of the root system is essential to adjust strategies and routines of irrigation and fertigation management, such as the position of emitters, moisture sensors and soil solution extractors (Coelho et al., 2008; 2015).

The different variables of the root system, such as total length, diameter, effective depth and distance of roots have been evaluated in bananas and plantains (Sant'Ana et al., 2012). Borges et al. (2008), who evaluated the distribution of 'Prata Anã' banana roots under two fertigation frequencies, found that the greatest concentration of roots occurred in the surface layers $(\leq 0.30 \mathrm{~m})$ and between the plant and the micro-sprinkler.

This study aimed to evaluate the effect of different trickle irrigation systems on the root spatial growth and root spatial distribution of banana cv. Prata Gorutuba.

\section{Material And Methods}

This study was carried out with the banana cv. Prata Gorutuba at the Experimental Station of Gorutuba, which belongs to the Empresa de Pesquisa Agropecuária de Minas Gerais (EPAMIG), in Nova Porteirinha, MG, Brazil, (15² 48'S, $43^{\circ} 18^{\prime} \mathrm{W}$, and $516 \mathrm{~m}$ a.s.l.).The climate of the region, according to Köppen's classification, is BSwh (hot climate of Caatinga) with a mean annual precipitation of $877 \mathrm{~mm}$ distributed in the summer and with well-defined dry periods in the winter. The soil of the experimental area is an Oxisol with a sandy clay loam texture up to the $0.60 \mathrm{~m}$ depth (Santos et al., 2016).

Irrigation was applied every day, and water depth was based upon crop evapotranspiration (Table 1), which was calculated by using reference evapotranspiration from Class A pan evaporation and reduction coefficient $(\mathrm{Kl})$ (Keller \& Bliesner, 1992) and crop coefficient (Kc) recommended by Allen et al. (1998).

The evaluation of root systems used a randomized block design with three repetitions, in a split-split-plot scheme, which considered the following sources of variation: the irrigation system in the plot; the distance from the plant in the subplot; and the depth of wetted soil in the sub-subplot. The experimental unit adopted was the soil profile opened between the banana plant and the emitter and/or lateral line of irrigation. The treatments were two irrigation systems: micro sprinkler system with three flow rates and drip system with two numbers of lateral lines per plant row. Micro-sprinkler flow rates were 35 (T1), 53 (T2) and 70 (T3) $\mathrm{L} \mathrm{h}^{-1}$, with precipitation rates of $0.8,1.4$ and $2.0 \mathrm{~mm} \mathrm{~h}^{-1}$, respectively. Lateral lines were in between two plant rows with micro-sprinkler emitters $4.0 \mathrm{~m}$ apart along laterals. The drip system emitter flow rate was 4.0 $\mathrm{L} \mathrm{h}^{-1}$ spaced by $0.70 \mathrm{~m}$ along lateral line with one lateral per plant row (T4) and with two lateral lines per plant row (T5). Evaluations occurred from the plant at distances: $0.25,0.50$, 0.75 and $1.0 \mathrm{~m}$, at the following soil depths: $0.10,0.20,0.40$, 0.60 and $0.80 \mathrm{~m}$.

Root samples were collected during the flower emergence of the banana crop, in soil pits $1.0 \mathrm{~m}$ long, $1.0 \mathrm{~m}$ deep and $0.80 \mathrm{~m}$ wide. They were dug from the banana plant longitudinally to the plant row for drip-irrigated treatments and from the plant to the micro-sprinkler for treatments under micro-sprinkler irrigation. Roots collected by using the monolith method (Majdi et al., 1992; Coelho et al., 2008) with samples of $1.0 \times 10^{-3} \mathrm{~m}^{3}$. Roots were separated from soil and digitized to TIFF files (Tagged Image File Format), which were processed with the ROOTEDGE program to obtain root length (Kaspar \& Ewing, 1997; Himmelbauer et al., 2004; Sant'Ana et al., 2012). The total root length, RL (cm) and the sample volume $\left(\mathrm{cm}^{3}\right)$ resulted in root length density, RLD ( $\mathrm{cm} \mathrm{cm}^{-3}$ ) (Sant'Ana et al., 2012). Root length data were evaluated at the effective depth and distance of the root system, i.e., those that concentrate $80 \%$ of the total length in the entire profile (Coelho et al., 2016).

The water use efficiency (WUE) of the crop, in each system, was calculated using the relation between the yield obtained and the total water layer applied during the first cycle of banana crop.

Analysis of variance used root length density, water use efficiency and yield data. Regression was applied for the distance from the plant and for the depth of the wetted soil. Tukey test was used for WUE and yield regarding the irrigation systems. Root length density data were also evaluated on twodimensional planes corresponding to soil profiles (distance and soil depth from the pseudostem)

\section{Results AND Discussion}

Most of root growth occurred during vegetative phase until flowering (June and July). Rainfall during the period of vegetative growth was $186 \mathrm{~mm}$ and occurred from February to May, but with a continuous water deficit in the soil (Table 1). Therefore, irrigation was necessary during all vegetative

Table 1. Monthly climate variables in $\mathrm{mm}$ of precipitation (Prec), reference evapotranspiration (ETo), soil water deficit (DEF) and water excess (Exc) during the first crop cycle of banana

\begin{tabular}{lcccccccccccc}
\hline & Jan. & Feb. & Mar. & Apr. & May & Jun. & Jul. & Aug. & Sep. & Oct. & Nov. & Dec. \\
Prec & 215 & 24 & 83 & 70 & 9 & 0 & 0 & 0 & 4 & 192 & 126 & 207 \\
ETo & 129 & 124 & 150 & 123 & 102 & 100 & 95 & 98 & 149 & 141 & 133 & 126 \\
Def & 0.0 & 56 & 62 & 51 & 92 & 100 & 95 & 98.4 & 145 & 0.0 & 0.4 & 0.0 \\
Exc & 86 & 0 & 0 & 0 & 0 & 0 & 0 & 0 & 0 & 1 & 0 & 74 \\
\hline
\end{tabular}


growth phase and rain was not relevant for root growth as irrigation was.

The analysis of variance showed a significant interaction $(\mathrm{p} \leq 0.05)$ between trickle irrigation systems and soil depth on root length density (RLD). Means of RLD of the treatments T1 $\left(35 \mathrm{~L} \mathrm{~h}^{-1}\right), \mathrm{T} 2\left(53 \mathrm{~L} \mathrm{~h}^{-1}\right)$ and drip irrigation with two lateral lines (T5) did not differ among layers in between the soil surface and $0.80 \mathrm{~m}$ depth. The means of RLD of the treatments T3 (70 $\mathrm{L} \mathrm{h}^{-1}$ ) and T4 obtained in shallower layers were statistically higher than in deeper layers (Table 2).

When comparing the means of RLD of irrigation system treatments for each soil depth (Table 2), there were significant differences only in the $0.10-0.20 \mathrm{~m}$ layer. The means of RLD for the 0.10-0.20 m layer in T3 and T4 were higher than those of the others systems. At the other depths, the means of RLD under the irrigation systems did not differ from each other. The smallest soil wetted area under drip irrigation, particularly that one with one lateral line per plant row (T4), concentrated greater root length per unit of soil volume. This also occurred for T3, possibly due to a lower flow rate of the micro-sprinkler of smaller wetted radius, resulting in an applied water depth lower than $1.5 \mathrm{~mm}$ in most of the wetted area (Figure 1). The micro-sprinkler systems of flow rates of 70 and $53 \mathrm{~L} \mathrm{~h}^{-1}$ and drip system with two lateral lines showed means of RLD which did not differ at any depth, although the values of the means indicate the same behavior for T3 and T4.

The highest value of RLD $\left(1.43 \mathrm{~cm} \mathrm{~cm}^{-3}\right.$, Table 2$)$ in the drip-irrigated treatment was observed with one lateral line per plant row (T4), which was smaller than that found by Sant'Ana et al. (2012). Those authors evaluated the root distribution of 'Prata Anã' banana under different irrigation systems in semiarid conditions and found root length densities of $2.12 \mathrm{~cm} \mathrm{~cm}^{-3}$ under drip irrigation. Results of RLD in this study are also smaller than the ones obtained by Coelho et al. (2008), who evaluated the banana root system under sub-humid climate conditions, for different configurations of trickle irrigation, and found root length densities from 1.6 to $2.2 \mathrm{~cm} \mathrm{~cm}^{-3}$ under drip irrigation. The results of RLD obtained at different distances of the systems showed a not significant variation, indicating that roots were not concentrated at a certain distance from the plant (Table 3 ).

Table 2. Means of root length density (RLD, $\mathrm{cm} \mathrm{cm}^{-3}$ ) of banana cv. Prata Gorutuba under different trickle irrigation systems and soil depths

\begin{tabular}{cccccc}
\hline Soil depth & \multicolumn{5}{c|}{ Irrigation systems } \\
\cline { 2 - 6 }$(\mathbf{m})$ & $\mathrm{T} 1$ & $\mathrm{~T} 2$ & $\mathrm{~T} 3$ & $\mathrm{~T} 4$ & T5 \\
$0-0.10$ & $0.95 \mathrm{Aa}$ & $0.96 \mathrm{Aa}$ & $1.11 \mathrm{Aa}$ & $1.05 \mathrm{ABa}$ & $0.97 \mathrm{ABa}$ \\
$0.10-0.20$ & $1.00 \mathrm{Ab}$ & $0.99 \mathrm{Ab}$ & $1.19 \mathrm{Aa}$ & $1.43 \mathrm{Aa}$ & $1.08 \mathrm{Ab}$ \\
$0.30-0.40$ & $0.99 \mathrm{Aa}$ & $0.97 \mathrm{Aa}$ & $0.98 \mathrm{ABa}$ & $1.00 \mathrm{ABa}$ & $0.95 \mathrm{ABa}$ \\
$0.50-0.60$ & $0.92 \mathrm{Aa}$ & $0.85 \mathrm{Aa}$ & $0.82 \mathrm{Ba}$ & $0.79 \mathrm{Ba}$ & $0.81 \mathrm{Ba}$ \\
$0.70-0.80$ & $0.88 \mathrm{Aa}$ & $0.83 \mathrm{Aa}$ & $0.77 \mathrm{Ba}$ & $0.76 \mathrm{Ba}$ & $0.78 \mathrm{Ba}$ \\
CV (\%)=16.29 & & & & & \\
\hline
\end{tabular}

T1 - Micro-sprinkler irrigation system with flow rate of $35 \mathrm{~L} \mathrm{~h}^{-1}$ and precipitation rate of 0.8 $\mathrm{mm} \mathrm{h}^{-1}$; T2 - Micro-sprinkler irrigation system with flow rate of $53 \mathrm{~L} \mathrm{~h}^{-1}$ and precipitation rate of $1.4 \mathrm{~mm} \mathrm{~h}^{-1}$; T3 - Micro-sprinkler irrigation system with flow rate of $70 \mathrm{~L} \mathrm{~h}^{-1}$ and precipitation rate of $2.0 \mathrm{~mm} \mathrm{~h}^{-1}$; T4 - Drip irrigation system with emitter flow rate of $4.0 \mathrm{~L} \mathrm{~h}^{-1}$ spaced by $0.70 \mathrm{~m}$ and with one lateral line per plant row; T5 - Drip irrigation system with emitter flow rate of $4.0 \mathrm{~L} \mathrm{~h}^{-1}$ spaced by $0.70 \mathrm{~m}$ and with two lateral lines per plant row; Means followed by the same letter, lowercase in the row and uppercase in the column, do not differ by Tukey test at $\mathrm{p} \leq 0.05$

${ }^{*}$ Data were transformed by sqrt $(\mathrm{Y}+0.5)$
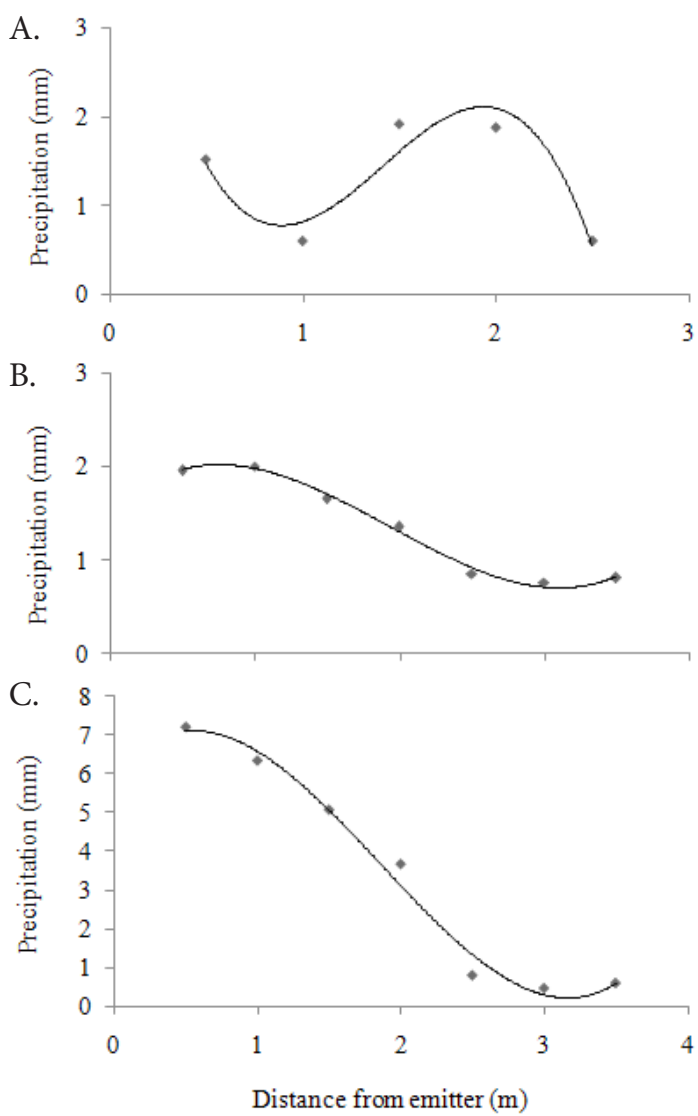

Figure1. Precipitation distribution of micro-sprinkler irrigation as a function of distance from emitter for treatments (A) T1-35 $\mathrm{L} \mathrm{h}^{-1}$; (B) T2-53 $\mathrm{L} \mathrm{h}^{-1}$; (C) T3-70 L h-1

Table 3. Means of root length density ( $\left.R L D, \mathrm{~cm} \mathrm{~cm}^{-3}\right)$ of banana cv. Prata Gorutuba under trickle irrigation systems and plant distance

\begin{tabular}{cccccc}
\hline Distance & \multicolumn{5}{c}{ Irrigation systems } \\
\cline { 2 - 6 }$(\mathbf{m})$ & T1 & T2 & T3 & T4 & T5 \\
0.25 & $0.414 \mathrm{Aa}$ & $0.351 \mathrm{Aa}$ & $0.645 \mathrm{Aa}$ & $0.493 \mathrm{Aa}$ & $0.265 \mathrm{Aa}$ \\
0.50 & $0.401 \mathrm{Aa}$ & $0.379 \mathrm{Aa}$ & $0.757 \mathrm{Aa}$ & $0.411 \mathrm{Aa}$ & $0.342 \mathrm{Aa}$ \\
0.75 & $0.408 \mathrm{Aa}$ & $0.386 \mathrm{Aa}$ & $0.382 \mathrm{Aa}$ & $0.855 \mathrm{Aa}$ & $0.561 \mathrm{Aa}$ \\
1.00 & $0.525 \mathrm{Aa}$ & $0.429 \mathrm{Aa}$ & $0.396 \mathrm{Aa}$ & $0.743 \mathrm{Aa}$ & $0.405 \mathrm{Aa}$ \\
$\mathrm{CV}(\%)=8.09$ & & & & & \\
\hline
\end{tabular}

T1 - Micro-sprinkler irrigation system with flow rate of $35 \mathrm{~L} \mathrm{~h}^{-1}$ and precipitation rate of 0.8 $\mathrm{mm} \mathrm{h}^{-1} ; \mathrm{T} 2$ - Micro-sprinkler irrigation system with flow rate of $53 \mathrm{~L} \mathrm{~h}^{-1}$ and precipitation rate of $1.4 \mathrm{~mm} \mathrm{~h}^{-1}$; T3 - Micro-sprinkler irrigation system with flow rate of $70 \mathrm{~L} \mathrm{~h}^{-1}$ and precipitation rate of $2.0 \mathrm{~mm} \mathrm{~h}^{-1}$; T4 - Drip irrigation system with emitter flow rate of $4.0 \mathrm{~L} \mathrm{~h}^{-1}$ spaced by $0.70 \mathrm{~m}$ and with one lateral line per plant row; T5 - Drip irrigation system with emitter flow rate of $4.0 \mathrm{~L} \mathrm{~h}^{-1}$ spaced by $0.70 \mathrm{~m}$ and with two lateral lines per plant row; Means followed by the same letter, lowercase in the row and uppercase in the column, do not differ by Tukey test at $\mathrm{p} \leq 0.05$

The percentage of cumulative root length showed a linear behavior as the distance from the plant increased (Figures $2 \mathrm{~A}$ and $\mathrm{C}$ ) and a second-degree polynomial behavior as the depth of the roots in the soil increased (Figures $2 \mathrm{~B}$ and D). The linear increase in the percentage of total root length in the profile with the distance indicates a continuity of roots at distances greater than the limit of the soil pit, which was at $1.0 \mathrm{~m}$. The quadratic polynomial increases in the percentage of cumulative root length with soil depth indicates a higher rate of increment up to the 0.40-0.50 m layer and a reduction in the rate of increment in the percentage of total root length from this layer.The percentage of cumulative root length indicated that the effective distance of the root system increased as the micro-sprinkler flow rate 

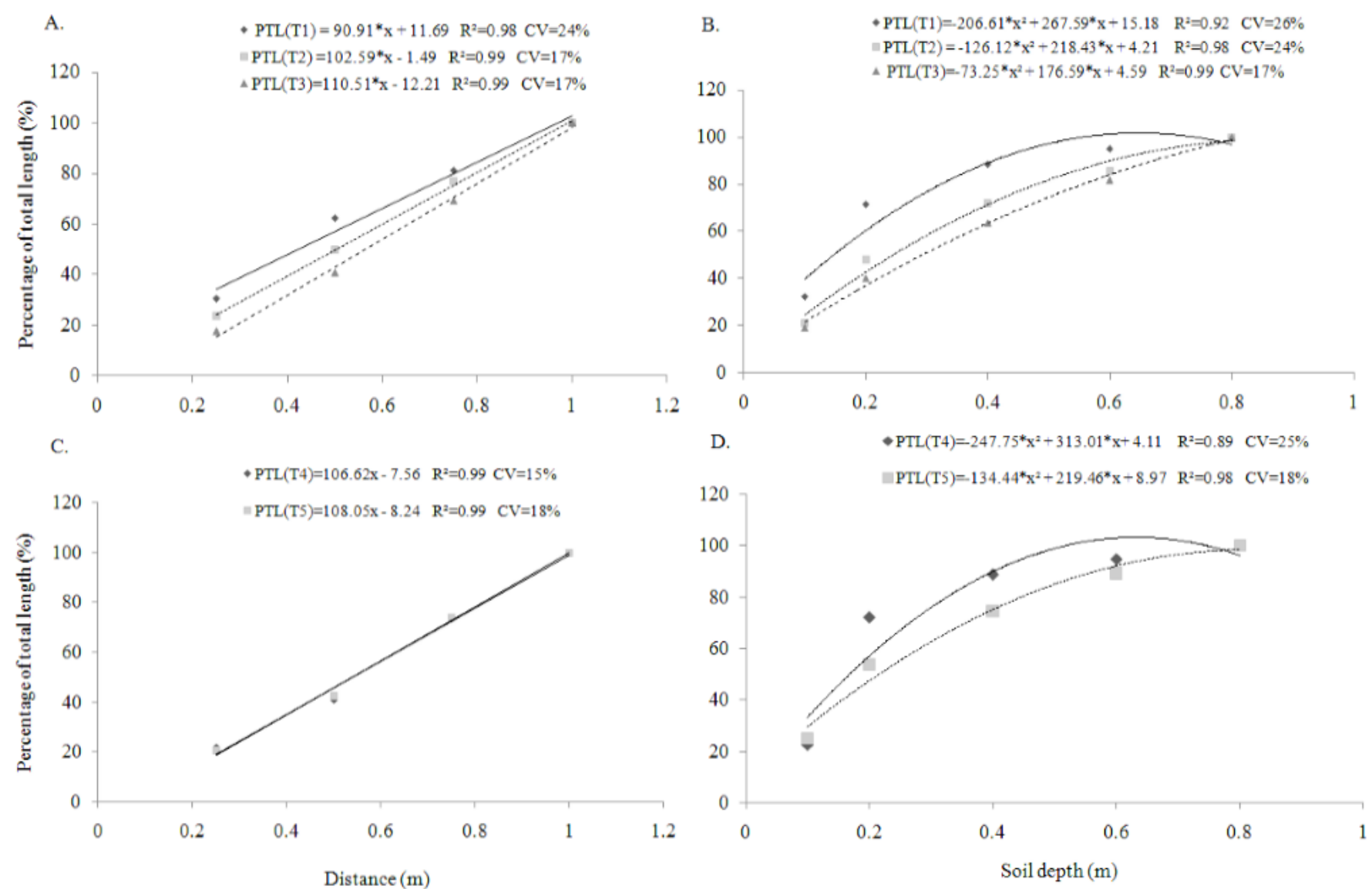

T1 - Micro-sprinkler irrigation system with flow rate of $35 \mathrm{~L} \mathrm{~h}^{-1}$ and precipitation rate of $0.8 \mathrm{~mm} \mathrm{~h}^{-1}$; T2 - Micro-sprinkler irrigation system with flow rate of $53 \mathrm{~L} \mathrm{~h}{ }^{-1}$ and precipitation rate of $1.4 \mathrm{~mm} \mathrm{~h}^{-1}$; T3 - Micro-sprinkler irrigation system with flow rate of $70 \mathrm{~L} \mathrm{~h}^{-1}$ and precipitation rate of $2.0 \mathrm{~mm} \mathrm{~h}^{-1}$; T4 - Drip irrigation system with emitter flow rate of $4.0 \mathrm{~L}$ $\mathrm{h}^{-1}$ spaced by $0.70 \mathrm{~m}$ and with one lateral line per plant row; T5 - Drip irrigation system with emitter flow rate of $4.0 \mathrm{~L} \mathrm{~h}^{-1}$ spaced by $0.70 \mathrm{~m}$ and with two lateral lines per plant row; * - Significant at $\mathrm{p} \leq 0.05$ by $\mathrm{F}$ test

Figure 2. Percentage of total root length (PTL) as a function of distance from plant $(\mathrm{A}, \mathrm{C})$ and soil depth (B, D) for microsprinkler $(\mathrm{A}, \mathrm{B})$ and drip $(\mathrm{C}, \mathrm{D})$ irrigation systems

increased, with $80 \%$ of the root system in the profile concentrated from plant up to $0.75 \mathrm{~m}$ for T3, $0.79 \mathrm{~m}$ for T2 and $0.83 \mathrm{~m}$ for $\mathrm{T} 1$. These values were in the same range from those obtained by Silva et al. (2012), which varied from 0.70 to $0.85 \mathrm{~m}$ for flow rates from 60 to $32 \mathrm{~L} \mathrm{~h}^{-1}$, respectively.

These results were higher than the ones found by Coelho et al. (2008), who evaluated root system distribution for the banana cV. BRS Tropical under different configurations of trickle irrigation. These authors concluded that $80 \%$ of the total root length occurred at a $0.70 \mathrm{~m}$ distance from the pseudostem for both irrigation systems, micro-sprinkler and drip under sub-humid conditions. The results obtained for drip systems may be explained by the proportion of clay and silt and the compacted soil structure (densities of $1.7 \mathrm{~kg} \mathrm{dm}^{-3}$ ), which affect the lateral expansion of the wet volume (Keller \& Bliesner, 1992). Regarding water distribution from the micro-sprinkler on the soil surface, the greatest accumulation occurred at distances up to $2.0 \mathrm{~m}$ from the emitter in accordance to its flow rate (Figure 1).

The results of the effective rooting depth confirmed the reports of Coelho et al. (2008), who stated that the banana root system normally has greater development in more superficial soil layers where organic matter is higher and the physical and chemical soil attributes favor root development. The effective soil depth ( $80 \%$ of the cumulative root length) in the treatments under micro-sprinkler irrigation (Figure 2) occurred at $0.55 \mathrm{~m}$ for
$\mathrm{T} 1,0.48 \mathrm{~m}$ for $\mathrm{T} 2$, and $0.32 \mathrm{~m}$ for $\mathrm{T} 3$ (Figure 2B). These results agreed with those obtained by Carr (2009), who found that, although banana roots extend up to depths greater than $1.0 \mathrm{~m}$, the effective rooting depth is usually between 0.40 and $0.60 \mathrm{~m}$.

As observed in the treatments under micro-sprinkler irrigation, the means of the percentage of total root length obtained in both drip irrigation treatments showed a linear behavior with the increase in the distance from one plant up to half the space between both. The effective rooting distance (Figure 2C) was $0.82 \mathrm{~m}$ for $\mathrm{T} 4$ and $0.81 \mathrm{~m}$ for T5. These results are higher than those found by Coelho et al. (2010), who evaluated the root distribution of the banana cv. BRS Tropical, under drip tape irrigation, and found an effective root distance of $0.70 \mathrm{~m}$. The behavior of horizontal root growth was virtually identical for both T4 and T5; at the horizontal distances between plants, the percentages of root length were 21.96 and $20.56 \%$ (at distance of $0.25 \mathrm{~m}$ ); 18.97 and $21.82 \%$ (at distance of $0.50 \mathrm{~m}$ ); 32.47 and $31.79 \%$ (at distance of $0.75 \mathrm{~m}$ ), and 26.57 and $25.81 \%$ (at distance of $1.0 \mathrm{~m}$ ), respectively. In these systems, the moisture resulting from the distribution of water was higher along the lateral line due to the superposition of the wetted volumes along the row.

The percentages of cumulative root length in the subsurface under drip and micro-sprinkler irrigation systems followed a quadratic behavior, with a greater concentration of roots at $0.40 \mathrm{~m}$. The effective rooting depth (Figure 2D) was $0.39 \mathrm{~m}$ for 
T4 and $0.44 \mathrm{~m}$ for T5. Root development in T4 was higher than that of $\mathrm{T} 5$ in the shallower layers, since $56.6 \%$ of the total root length was concentrated at $0.20 \mathrm{~m}$ depth, different from $\mathrm{T} 5$, in which there was a concentration of only $47.5 \%$ of the total root length. The behavior presented in Figure 2D illustrates larger water volumes per unit of time applied by drip irrigation for smaller wetted areas (T4) that favor a greater concentration of roots in the most superficial soil layer.

There was a significant difference of RLD means among the different soil layers evaluated at the same distance from the plant for all treatments. The differences of RLD means among distances from the plant only occurred in the $0.30-0.40 \mathrm{~m}$ layer (Table 4).

The means of RLD in the $0.10-0.20 \mathrm{~m}$ layer were superior to those in the deeper layers $(0.30-0.40,0.50-0.60$ and $0.70-0.80 \mathrm{~m}$ ). The mean of RLD in the $0.10-0.20 \mathrm{~m}$ layer did not differ from that in the $0.30-0.40 \mathrm{~m}$ layer, except at $0.75 \mathrm{~m}$ from the plant, indicating that most of the root system was concentrated in this layer (Table 4). A significant difference only occurred between the means of RLD for the $0.30-0.40 \mathrm{~m}$ layer, and the means of RLD at a $0.75 \mathrm{~m}$ distance from the plant was superior in relation to the others. Sant'Ana et al. (2012) found the highest values of RLD at $0.45 \mathrm{~m}$ distance from the plant and at $0.40 \mathrm{~m}$ depth.

In general, root distribution in the soil profile for both drip and micro-sprinkler systems, and according to several authors
Table 4. Means of root length density (RLD, $\mathrm{cm} \mathrm{cm}^{-3}$ ) within each distance for all treatments

\begin{tabular}{ccccc}
\hline \multirow{2}{*}{$\begin{array}{c}\text { Depth } \\
\text { (m) }\end{array}$} & \multicolumn{4}{c}{ Distance (m) } \\
\cline { 2 - 5 } $0-0.10$ & $\mathbf{0 . 2 5}$ & $\mathbf{0 . 5}$ & $\mathbf{0 . 7 5}$ & $\mathbf{1 . 0 0}$ \\
$0.10-0.20$ & $1.119 \mathrm{ABa}$ & $1.009 \mathrm{ABa}$ & $1.016 \mathrm{ABa}$ & $1.011 \mathrm{ABa}$ \\
$0.30-0.40$ & $0.916 \mathrm{Bb}$ & $0.923 \mathrm{Bb}$ & $1.082 \mathrm{ABa}$ & $1.021 \mathrm{Aa}$ \\
$0.50-0.60$ & $0.841 \mathrm{Ba}$ & $0.820 \mathrm{Ba}$ & $0.864 \mathrm{BCa}$ & $0.968 \mathrm{Bb}$ \\
$0.70-0.80$ & $0.801 \mathrm{Ba}$ & $0.802 \mathrm{Ba}$ & $0.791 \mathrm{Ca}$ & $0.839 \mathrm{Ba}$ \\
CV $(\%)=24.37$ & & & & \\
\hline
\end{tabular}

Means followed by the same letter, lowercase in the row and uppercase in the column, do not differ by Tukey test at $\mathrm{p} \leq 0.05$

${ }^{*}$ Data were transformed by $\operatorname{sqrt}(\mathrm{Y}+0.5)$

(Coelho et al., 2008; Sant'Ana et al., 2012; Silva et al., 2012), was higher closer to the soil surface, with a greater concentration of the root system in the soil layer between the depths of 0.10 and $0.40 \mathrm{~m}$ (Figure 3 ).

For treatments under micro-sprinkler irrigation, root distribution in T3 was more superficial than in T2 and T1. There was a greater concentration of roots up to the $0.3 \mathrm{~m}$ depth and up to half the distance between the plant and the micro-sprinkler, which was located $1.0 \mathrm{~m}$ from the plant. These results agree with the ones obtained by Silva et al. (2012) for flow rates from 60 to $32 \mathrm{~L} \mathrm{~h}^{-1}$. The treatments T1 and T2 showed root development at greater depths, with growth from the base of the plant up to areas close to the micro-sprinkler, exploring almost the entire area of the evaluated soil profile. A different result was reported by Sant'Ana et al. (2012), who evaluated

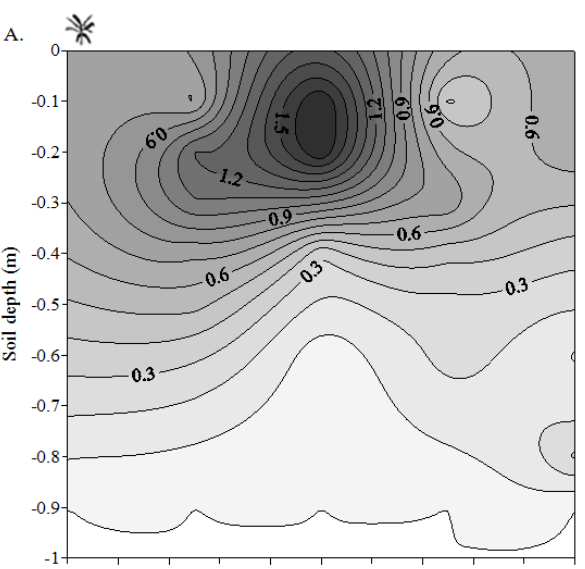

B. *ैh
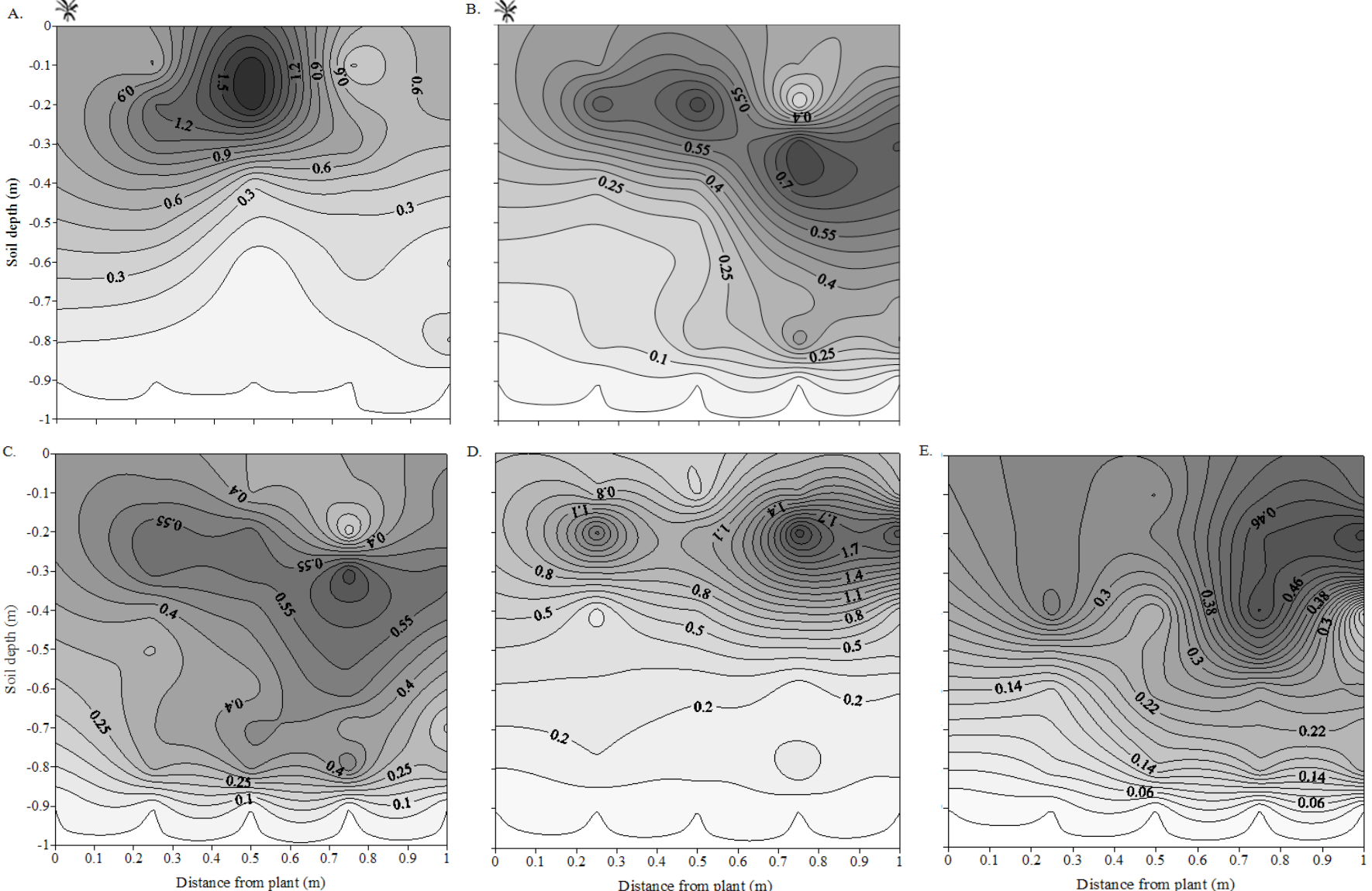

1 - Micro-sprinkler irrigation system with flow rate of $35 \mathrm{~L} \mathrm{~h}^{-1}$ and precipitation rate of $0.8 \mathrm{~mm} \mathrm{~h}^{-1}$; T2 - Micro-sprinkler irrigation system with flow rate of $53 \mathrm{~L} \mathrm{~h}$ and precipitation rate of $1.4 \mathrm{~mm} \mathrm{~h}^{-1}$; T3 - Micro-sprinkler irrigation system with flow rate of $70 \mathrm{~L} \mathrm{~h}^{-1}$ and precipitation rate of $2.0 \mathrm{~mm} \mathrm{~h}^{-1}$; T4 - Drip irrigation system with emitter flow rate of $4.0 \mathrm{~L}$ $\mathrm{h}^{-1}$ spaced by $0.70 \mathrm{~m}$ and with one lateral line per plant row; T5 - Drip irrigation system with emitter flow rate of $4.0 \mathrm{~L} \mathrm{~h}^{-1}$ spaced by $0.70 \mathrm{~m}$ and with two lateral lines per plant row

Figure 3. Soil profile with lines of same root length density for treatments with micro-sprinkler and drip irrigation systems: T1 (A), T2 (B), T3 (C), T4 (D) and T5 (E) 
root distribution under irrigation with a micro-sprinkler of $70 \mathrm{~L} \mathrm{~h}^{-1}$ and found a greater concentration of roots up to $0.40 \mathrm{~m}$ depth and at a $0.70 \mathrm{~m}$ distance from the plant.

The root system showed a shallower distribution in T4 (one lateral line), which is demonstrated by the effective depth of the roots of $0.33 \mathrm{~m}$. The effective root distance was about $0.82 \mathrm{~m}$ for the drip systems of treatments T4 and T5. The lateral expansion of roots was limited by the lateral borders of the wetted volumes, which extended horizontally up to $1.0 \mathrm{~m}$ from the plant. The results found by Sant'Ana et al. (2012) were higher than the ones obtained in $\mathrm{T} 4$ with respect to effective rooting depth, since those authors found a depth of $0.54 \mathrm{~m}$, but the effective distance from the plant was $0.57 \mathrm{~m}$, smaller than that in T4. In T5 (drip irrigation with two lateral lines), root system distribution within the soil profile was more uniform in the soil layer extending up to $1.0 \mathrm{~m}$ distance from the plant and to $0.40 \mathrm{~m}$ depth when compared with $\mathrm{T} 4$. The majority of the total root length $(80 \%)$ in $\mathrm{T} 5$ found at $0.81 \mathrm{~m}$ from the plant. These means are higher than the ones reported by Silva (2009), who evaluated root distribution under drip irrigation with two lateral lines and found $80 \%$ of the total root length at $0.30 \mathrm{~m}$ depth and at a $0.70 \mathrm{~m}$ distance from the plant.

Yields and water use efficiency (WUE) were higher and did not differ among T5 (drip with two laterals per plant row), T1 (micro-sprinkler - $35 \mathrm{~L} \mathrm{~h}^{-1}$ ) and T2 (micro-sprinkler - $53 \mathrm{~L} \mathrm{~h}^{-1}$ ). These treatments differed significantly from treatments $\mathrm{T} 3$ (micro-sprinkler - $70 \mathrm{~L} \mathrm{~h}^{-1}$ ) and T4 (drip with one lateral per plant row) (Figure 4).

Root growth was more intense for irrigation systems with larger wetted areas like micro-sprinkler with flow rate equal or above $53 \mathrm{~L} \mathrm{~h}^{-1}(\mathrm{~T} 1, \mathrm{~T} 2)$, and drip system with two laterals per plant row (T5). Root growth was also more intense up to the effective root distance from plant that ranged from $0.79 \mathrm{~m}$ (T2) to $0.83 \mathrm{~m}$ (T1) (Figure 2). The larger total root length and effective root distance means larger soil root volume or higher number of roots for water and nutrient uptake. This enables plants to grow, to produce more, and to increase water use efficiency as shown by the yields of treatments $\mathrm{T} 1, \mathrm{~T} 2$ and $\mathrm{T} 5$, which did not differ.

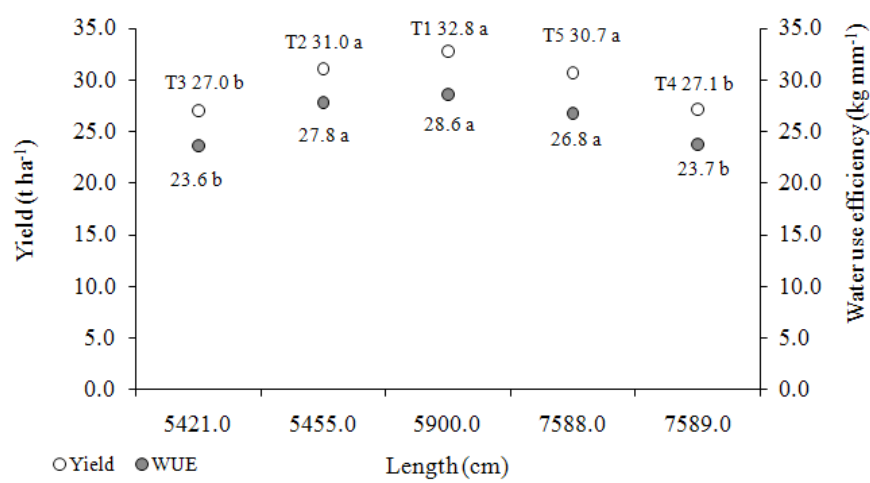

T1 - Micro-sprinkler irrigation system with flow rate of $35 \mathrm{~L} \mathrm{~h}^{-1}$ and precipitation rate of 0.8 $\mathrm{mm} \mathrm{h}^{-1} ; \mathrm{T} 2$ - Micro-sprinkler irrigation system with flow rate of $53 \mathrm{~L} \mathrm{~h}^{-1}$ and precipitation rate of $1.4 \mathrm{~mm} \mathrm{~h}^{-1} ; \mathrm{T} 3$ - Micro-sprinkler irrigation system with flow rate of $70 \mathrm{~L} \mathrm{~h}^{-1}$ and precipitation rate of $2.0 \mathrm{~mm} \mathrm{~h}^{-1}$; T4 - Drip irrigation system with emitter flow rate of 4.0 $\mathrm{L} \mathrm{h}^{-1}$ spaced by $0.70 \mathrm{~m}$ and with one lateral line per plant row; $\mathrm{T} 5$ - Drip irrigation system with emitter flow rate of $4.0 \mathrm{~L} \mathrm{~h}^{-1}$ spaced by $0.70 \mathrm{~m}$ and with two lateral lines per plant row Figure 4. Yield and water use efficiency (WUE) of banana cv. Prata Gorutuba in relation to total root length under different trickle irrigation systems

\section{Conclusions}

1. The irrigation system influences root distribution in the soil profile either in depth or in distance from the plant.

2. The effective distances from the plant and the effective depths of the roots increased with the increase in microsprinkler flow rates and were not different from the effective root distance and depth from plants irrigated by drip systems with one and two lateral lines.

3. The cumulative root length was linear with distance from the plant and followed a second-degree polynomial function with depth from soil surface.

4. The effective rooting distance from the plant ranged from 0.75 to $0.83 \mathrm{~m}$ and the effective rooting depth ranged from 0.36 to $0.57 \mathrm{~m}$.

\section{Literature Cited}

Allen, R. G.; Pereira, L. S.; Raes, D.; Smith, M. Crop evapotranspiration: Guidelines for computing crop water requirements. Rome: FAO, 1998. 300p. Irrigation and Drainage Paper, 56.

Borges, A. L.; Souza, L. S.; Peixoto, C. A. B.; Santos Júnior, J. L. C. Distribuição do sistema radicular da bananeira "Prata-Anã" em duas frequências de fertirrigação com uréia. Revista Brasileira de Fruticultura, v.30, p.259-262, 2008. https://doi.org/10.1590/ S0100-29452008000100048

Carr, M. K. V. The water relations and irrigation requirements of banana (Musa spp.). Experimental Agriculture, v.45, p.333-371, 2009. https://doi.org/10.1017/S001447970900787X

Coelho, E. F.; Melo, D. M.; Pereira, B. L. S.; Santos, D. B.; Rosa, R. C. C. Roots of 'BRS Princesa' banana fertigated with humic substances and saponin-based plant extracts. Acta Scientiarum Agronomy, v.38, p.521-528, 2016. https://doi.org/10.4025/ actasciagron.v38i4.30790

Coelho, E. F.; Silva, A. J. P.; Donato, S. L. R.; Santana Junior, E. B.; Oliveira, P. M. Sistemas de irrigação localizada e manejo de água em bananeira. Informe Agropecuário, v.36, p.62-73, 2015.

Coelho, E. F.; Silva, A. J. P.; Miranda, J. H. Definição do posicionamento de sensores para monitoramento da água no solo em bananeira irrigada por diferentes sistemas de irrigação localizada. Engenharia Agrícola, v.30, p.608-618, 2010. https://doi. org/10.1590/S0100-69162010000400005

Coelho, E. F.; Simões, W. L.; Carvalho, J. E. B.; Coelho Filho, M. A. Distribuição de raízes e extração de água do solo em fruteiras tropicais sob irrigação. Cruz das Almas: Embrapa Mandioca e Fruticultura Tropical, 2008. 80p.

Himmelbauer, M. L.; Loiskandl, W.; Kastanek, F. Estimating length, average diameter and surface area of roots using two different image analyses systems. Plant Soil, v.260, p.111-120, 2004. https:// doi.org/10.1023/B:PLSO.0000030171.28821.55

Kaspar, T. C.; Ewing, R. P. Rootedge: Software for measuring root length from desktop scanner images. Agronomy Journal, v.89, p.932-940, 1997. https://doi.org/10.2134/agronj1997.00021962 $008900060014 \mathrm{x}$

Keller, J.; Bliesner, R. D. Sprinkle and trickle irrigation. New York: AVI book, 1992.652p. 
Majdi, H.; Smucker, A. J. M.; Persson, H. A comparison between minirhizotron and monolith sampling methods for measuring root-growth of maize (Zea mays L.). Plant Soil, v. 147, p.127-134, 1992. https://doi.org/10.1007/BF00009378

Pawar, D. D.; Dingre, S. K.; Bhoi, P. G. Productivity and economics of drip-irrigated banana (Musa spp.) under different planting and fertigation techniques in subtropical India. Communications in Soil Science and Plant Analysis, v.48, p.449-458, 2017. https://doi. org/10.1080/00103624.2017.1282505

Pramanik, S.; Lai, S.; Ray, R.; Patra, S. K. Effect of drip fertigation on yield, water use efficiency, and nutrients availability in banana in West Bengal, India. Communications in Soil Science and Plant Analysis, v.47, p.1691-1700, 2016. https://doi.org/10.1080/0010 3624.2016.1206560

Ramos, C. M. C. Distribuição do sistema radicular e consumo de água da bananeira irrigada por microaspersão. Viçosa: UFV, 2001. 62p. Dissertação Mestrado
Sant'Ana, J. A. V.; Coelho, E. F.; Faria, M. A.; Silva, E. L.; Donato, S. L. R. Distribuição de raízes de bananeira 'Prata-Anã' no segundo ciclo de produção sob três sistemas de irrigação. Revista Brasileira de Fruticultura, v.34, p.124-133, 2012. https://doi.org/10.1590/ S0100-29452012000100018

Santos, M. R.; Coelho, E. F.; Donato, S. L. R.; Rodrigues, M. G. V. Distribuição de raízes e extração de água da bananeira 'BRS Princesa' sob diferentes configurações de irrigação. Engenharia na Agricultura, v.24, p.513-522, 2016. https://doi.org/10.13083/ reveng.v24i6.701

Silva, A. J. P. Variáveis de eficiência, manejo de irrigação e de produção da bananeira cultivar BRS Tropical sob diferentes sistemas de microaspersão e gotejamento. Piracicaba: ESALQ/USP, 2009. 71p. Dissertação Mestrado

Silva, A. J. P.; Coelho, E. F.; Miranda, J. H. Sensor placement for irrigation scheduling in banana using micro-sprinkler system. Water Resources and Irrigation Management, v.1, p.15-23, 2012. 